\title{
KETERAMPILAN BERBAHASA MENULIS TEKS EKSPOSISI
}

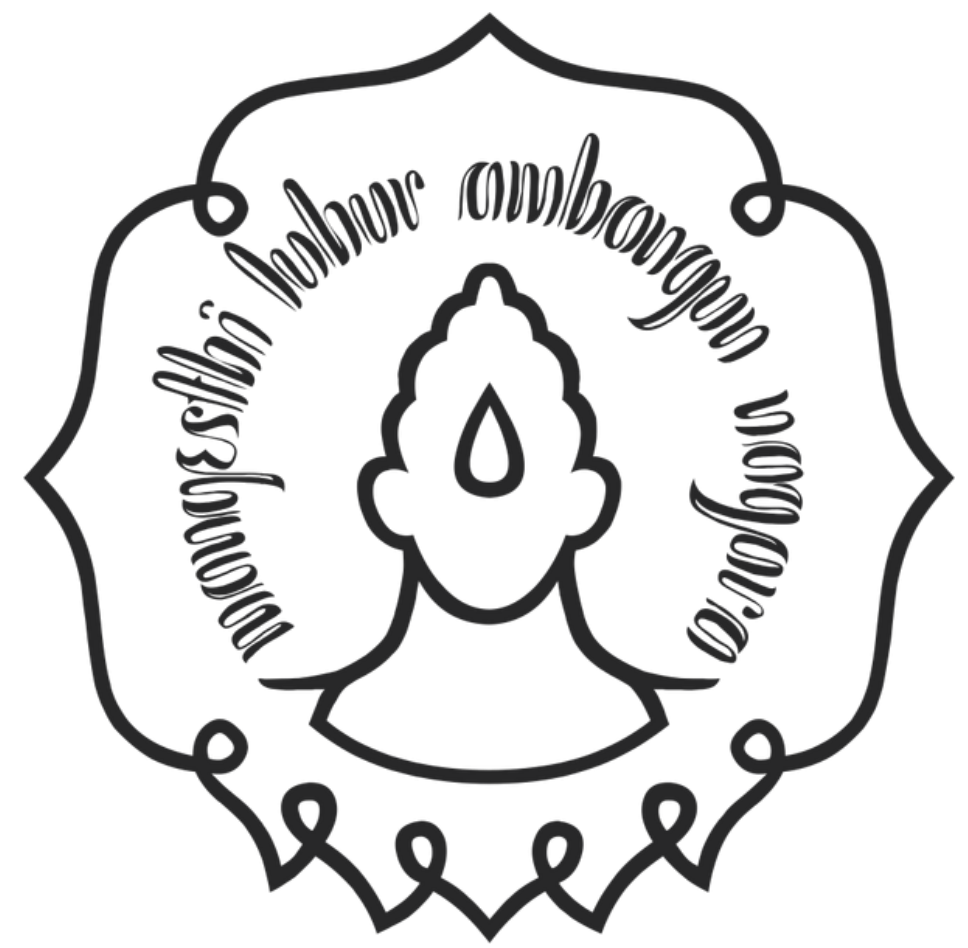

INDANA LAZULFA

K1217032

PROGRAM STUDI PENDIDIKAN BAHASA INDONESIA

FAKULTAS KEGURUAN DAN ILMU PENDIDIKAN

UNIVERSITAS SEBELAS MARET

SURAKARTA 


\section{Keterampilan Menulis Teks Eksposisi}

\section{Pengertian Menulis}

Menurut Tarigan (2008:3-4) menulis merupakan suatu keterampilan berbahasa yang dipergunakan untuk berkomunikasi secara tidak langsung, tanpa bertatap muka dengan orang lain. Sedangkan menurut Dalman (2016: 3) menulis merupakan suatu kegiatan komunikasi berupa penyampaian pesan (informasi) secara tertulis kepada pihak lain dengan menggunakan bahasa tulis sebagai alat atau medianya. Sementara menurut Mulyati (dalam Mundziroh, dkk, 2013) menulis adalah suatu proses berfikir dan menuangkan pemikiran itu dalam bentuk wacana (karangan).

Menulis merupakan salah satu keterampilan dasar berbahasa yang harus dimiliki manusia selain menyimak, berbicara, dan membaca. Keterampilan menulis bisa dilakukan oleh siapa saja yang sebelumnya sudah memiliki keterampilan dasar berbahasa yang lain. Sebab menulis merupakan keterampilan yang berkesinambungan dari keterampilan sebelumnya. Terlebih saat ini kurikulum yang berlaku adalah Kurikulum 2013 yang mana menuntuk siswa untuk berfikir kritis menggunakan pendekatan ilmiah (scientific approach). The scientific approach is defined as the learning way to facilitate the students to gain the knowledge and ability (Indrilla dan Ciptaningrum, 2018).

\section{Tujuan Menulis}

Segala hal yang dilakukan pasti memiliki tujuan, salah satunya menulis. Kegiatan menulis dilakukan dengan adanya tujuan tertentu. Misalnya mengungkapkan pikiran yang tidak bisa diucapkan, menghilangkan rasa bosan dan mecatat sesuatu agar tidak terlupa. Menurut Dalman (2015) tujuan menulis dapat dikelompokkan menjadi tiga, yaitu menulis dengan tujuan untuk studi, menulis dengan tujuan untuk usaha, dan menulis dengan tujuan kesenangan (hiburan). Sementara itu, menurut Kaplan (dalam Ghazali, 2013) menyatakan bahwa pada dasarnya ada empat jenis kegiatan menulis: 1) Menulis tanpa menyusun (mengisi tempat yang kosong dalam teks, mengisi formulir, membuat transkripsi dari pembicaraan lisan atau membuat daftar kata), 2) Menulis untuk tujuan informasional (membuat catatan, membuat laporan, membuat ringkasan), 3) Menulis untuk tujuan pribadi (membuat buku harian, memo, catatan-catatan pribadi), 4) Menulis untuk tujuan imajinatif (membuat cerita, drama, atau puisi).

\section{Manfaat Menulis}

Dengan menulis banyak sekali manfaat yang bisa didapatkan. Manfaat menulis bisa dirasakan oleh diri sendiri maupun orang lain yang membaca tulisan tersebut. Komaidi (2007:12-13) mengemukakan enam manfaat menulis, yaitu sebagai berikut. "Pertama, untuk menimbulkan rasa ingin tahu (curiocity) dan melatih kepekaan dalam melihat realitas di sekitar. 
Kedua, melalui kegiatan menulis, mendorong seseorang untuk mencari referensi seperti buku, majalah, koran, dan jurnal. Melalui kegiatan tersebut, akan menambah wawasan dan pengetahuan tentang apa yang ditulis. Ketiga, melalui kegiatan menulis, terlatih untuk menyusun pemikiran dan argumen secara runtut, sistematis, dan logis. Keempat, melalui kegiatan menulis, secara psikologis akan mengurangi tingkat ketegangan dan stres. Kelima, melalui kegiatan menulis, apabila hasil tulisan dimuat oleh media massa atau diterbitkan oleh suatu penerbit, akan memperoleh kepuasan batin karena tulisannya dianggap bermanfaat bagi orang lain. Selain itu, juga memperoleh honorarium (penghargaan). Keenam, mendapatkan popularitas apabila tulisannya dibaca oleh banyak orang. Hal ini akan memperoleh kepuasan tersendiri dan merasa dihargai oleh orang lain."

Manfaat khusus kegiatan menulis bagi kalangan akademik adalah mampu memberikan gagasan kepada suatu permasalahan global. Bahasa dapat merujuk pada pengalaman kehidupan manusia. Segala pengalaman kehidupan diungkapkan ketika berbicara, berinteraksi dengan orang lain, dan menuliskannya melalui bahasa tulis. (Oktaria, dkk, 2017)

\section{Karangan Eksposisi}

Dalam Kamus Besar Bahasa Indonesia disebutkan bahwa karangan eksposisi adalah karangan yang berupa petunjuk, uraian atau paparan tentang suatu maksud dan tujuan. Melalui tulisan eskposisi, seseorang bisa menjelaskan atau menerangkan suatu kejadian atau peristiwa sehingga menambah pengetahuan pembaca (Ariningsih, dkk, 2012). Sedikit berbeda dengan pendapat Dalman (2016: 120) yang menyatakan bahwa karangan eksposisi adalah karangan yang menjelaskan atau memaparkan pendapat, gagasan, keyakinan, yang memerlukan fakta yang diperkuat dengan angka statistik, peta dan grafik, tetapi tidak memengaruhi pembaca. Sedangkan menurut Keraf (1995: 7) menyatakan bahwa eksposisi adalah suatu bentuk wacana yang berusaha menguraikan suatu objek sehingga memperluas pandangan atau pengetahuan pembaca. Wacana ini digunakan untuk menjelaskan wujud dan hakekat suatu objek, misalnya menjelaskan pengertian kebudayaan, komunikasi, perkembangan teknologi, pertumbuhan ekonomi kepada pembaca.

\section{Ciri - ciri Karangan Eksposisi}

Materi menulis teks eksposisi bukan termasuk jenis teks baru dalam pembelajaran bahasa Indonesia. Akan tetapi, struktur teks eksposisi dalam Kurikulum 2013 muncul dengan istilah yang berbeda, yaitu pernyataan pendapat (pendahuluan), argumen (isi), dan pernyataan pendapat (penutup) (Nur'aini, dkk, 2015). Selain itu menurut Alwasilah dan Alwasilah (2013: 111) eksposisi mengandalkan strategi pengembangan alenia seperti lewat pemberian contoh, proses, sebab-akibat, klasifikasi, definisi, analisis, komparasi dan kontras. 
Ada beberapa ciri karangan eksposisi menurut Mariskan (Dalman, 2016: 120), yaitu: (1)Paparan itu karangan yang berisi pendapat, gagasan, keyakinan. (2) Paparan memerlukan fakta yang diperlukan dengan angka, statistik, peta, grafik. (3) Paparan memerlukan analisis dan sintesis. (4) Paparan menggali sumber ide dari pengalaman, pengamatan, dan penelitian, serta sikap dan keyakinan. (5) Paparan menjauhi sumber daya khayal. (6) Bahasa yang dipergunakan adalah bahasa yang informatif dengan kata-kata denotatif. (7) Penutup paparan berisi penegasan.

\section{Masalah dalam Menulis Karangan Eksposisi}

Dalam Kurikulum 2013 siswa dituntut untuk aktif, namun pada beberapa siswa masalah akan dijumpai ketika siswa mulai menulis. Masalah-masalah yang dihadapi siswa antara lain : (1) sulit menentukan tema; (2) keterbatasan informasi yang disebabkan kurangnya referensi; (3) adanya rasa malas atau bosan; dan (4) penguasaan kaidah bahasa yang kurang baik (Ariningsih, dkk, 2012). Selain hal tersebut ada beberapa masalah lain, yaitu: (1) Rendahnya motivasi menulis siswa; (2) Siswa kesulitan dalam menuangkan ide atau gagasan; (3) Perbendaharaan kata siswa rendah; (4) Penggunaan metode ceramah yang masih diterapkan guru (Wulandari, dkk, 2015).

Masalah tersebut tentu saja bisa diatasi. Dengan melakukan kegiatan berikut kesalahan menulis siswa kan berkurang. 1) meningkatkan penguasaan kaidah bahasa pada siswa, 2) memperbanyak latihan menulis, 3) menerapkan teknik koreksi yang tepat, 4) pelaksanaan pembelajaran menulis dengan pendekatan proses (Ariningsih, dkk, 2012). 
Alwasilah, A. C. dan S.S. Alwasilah. 2013. Pokoknya Menulis. Bandung: PT Kiblat Buku Utama.

Ariningsih, N.E., Sumarwati, dan K. Saddhono. 2012. Analisis Kesalahan Berbahasa Indonesia dalam Karangan Eksposisi Siswa Sekolah Menengah Atas. Basastra 1 (1).

Dalman. 2015. Penulisan Populer. Jakarta: PT RajaGrafindo Persada.

Dalman. 2016. Keterampilan Menulis. Jakarta: PT RajaGrafindo Persada.

Ghazali, S. 2013. Pembelajaran Keterampilan Berbahasa dengan Pendekatan komunikatifInteraktif. Bandung: PT Refika Aditama.

Indrilla, N. dan D.S. Ciptaningrum. 2018. An Approach In Teaching Writing Skills: Does It Offer A New Insight In Enhancing Student' Writing Ability. doi.org/10.24071/11t.2018.210201

Keraf, G. 1995. Eksposisi: Komposisi Lanjutan II. Jakarta: PT Grasindo.

Mahargyani, A.D., Herman J. Waluyo, dan K. Saddhono. 2012. Peningkatan Kemampuan Menulis Deskripsi dengan menggunakan Metode Field Trip pada Siswa Sekolah Dasar. Basastra. 1(1):4-5.

Mundziroh, S., Andayani, dan K. Saddhono. 2013. Peningkatan Kemampuan Menulis Cerita Dengan Menggunakan Metode Picture And Picture pada Siswa Sekolah Dasar. Basastra 2 (1).

Mulyati, Y. 2008. Keterampilan Berbahasa Indonesia SD. Jakarta: Universitas Terbuka.

Nur'aini, H.I.M., K. Saddhono, dan C. Ulya. 2015. Implementasi Kurikulum 2013 pada Pembelajaran Menulis Teks Eksposisi (Studi Kasus Di Kelas X SMK NEGERI 1 KARANGANYAR). Basastra 3 (3).

Oktaria, D., Andayani, dan K. Saddhono. 2017. Penguasaan Kalimat Efektif sebagai Kunci Peningkatan Keterampilan Menulis Eksposisi. http://dx.doi.org/10.26499/metalingua.v15i2.63

Pujiono, S. 2013. Terampil Menulis: Cara Mudah dan Praktik dalam Menulis. Yogyakarta: Graha Ilmu.

Semi, A.M. 1990. Menulis Efektif. Padang: Angkasa Raya

Tarigan, Henry Guntur. 2008. Menulis Sebagai Suatu Keterampilan Berbahasa. Bandung : Angkasa. 
Wulandari, Y.T., E. Suryanto, dan K. Saddhono. 2015. Penerapan Metode Picture And Picture Untuk Meningkatkan Motivasi dan Keterampilan Menulis Teks Narasi pada Siswa Sekolah Menengah Kejuruan. Basastra 3(2) 